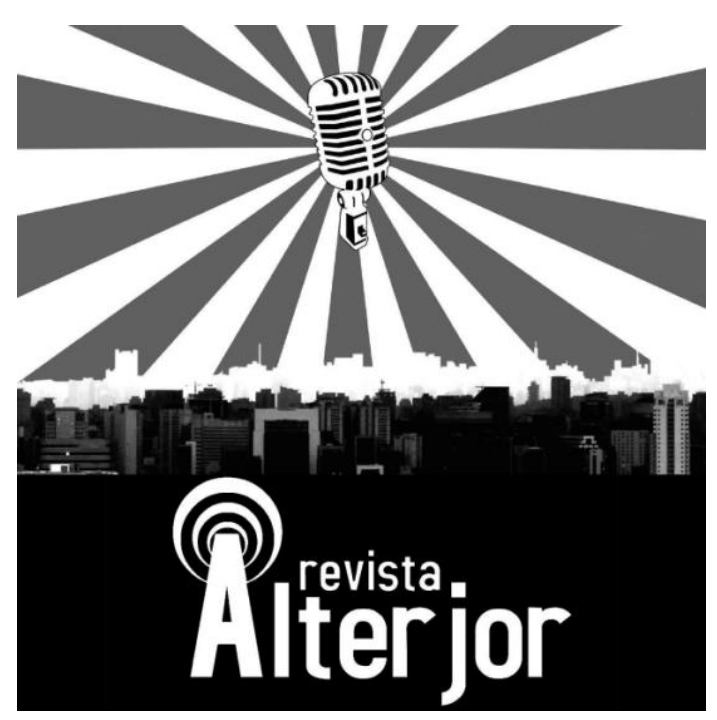

ENTREVISTA

\title{
RODOLFO WOLFGANG ORTRIWANO - RELATO SOBRE A IRMÃ GISELA SWETLANA, REFERÊNCIA NOS ESTUDOS DE RÁDIO NO BRASIL
}

\author{
Lourival da Cruz Galvão Júnior ${ }^{1}$
}

\begin{abstract}
RESUMO: Gisela Swetlana Ortriwano dedicou quase três décadas à pesquisa e ao ensino do rádio e do radiojornalismo no Departamento de Jornalismo e Editoração da Escola de Comunicações e Artes da Universidade de São Paulo (CJE-ECA/USP). Professora Gisela cursou duas faculdades, fez mestrado e doutorado também na USP, onde ainda se tornou pioneira ao defender a primeira tese que tratou de forma específica de radiojornalismo no Brasil. Todavia, pouco se sabe do percurso biográfico da docente, fato que motivou a entrevista com Rodolfo Wolfgang Ortriwano, professor, jornalista aposentado e irmão mais novo de Gisela. Como metodologia foram utilizados os preceitos da história oral, que revelaram uma trajetória forjada na dedicação ao estudo e ao rádio.
\end{abstract}

PALAVRAS-CHAVE: Memória. Rádio. Radiojornalismo. Ortriwano.

ABSTRACT: Gisela Swetlana Ortriwano has dedicated almost three decades to research and teaching radio and radiojournalism in the Department of Journalism and Publishing at the School of Communications and Arts at the University of São Paulo (CJE-ECA / USP). Teacher Gisela attended two colleges, did a master's and doctorate also at USP, where she also became a pioneer in defending the first thesis that dealt specifically with radiojournalism in Brazil. However, little is known about the teacher's biographical path, a fact that motivated the interview with Rodolfo Wolfgang Ortriwano, professor, retired journalist and Gisela's younger brother. As methodology, the precepts of oral history were used, which revealed a trajectory forged in dedication to study and to radio.

KEYWORDS: Memory. Radio. Radiojournalism. Ortriwano.

\footnotetext{
Professor-assistente no Departamento de Comunicação Social e docente e pesquisador nos Mestrados Profissional em Gestão e Desenvolvimento Regional e Acadêmico em Planejamento e Desenvolvimento Regional da Universidade de Taubaté (UNITAU). Coordena os cursos de Jornalismo e de Publicidade e Propaganda do Centro Universitário Módulo, em Caraguatatuba/SP. Graduado em Jornalismo, é mestre em Linguística Aplicada pela UNITAU e doutor em Ciências da Comunicação pela ECA/USP, onde faz pós-doutorado com supervisão do Prof. Dr. Luciano Victor Barros Maluly. E-mail: galvaojr@uol.com.br
}

Revista AL TERJOR

Grupo de Estudos Alterjor: Jornalismo Popular e Alternativo (ECA-USP)

Ano 10 Volume 02 Edição 22 Julho-Dezembro de 2020

Avenida Professor Lúcio Martins Rodriģues, 443, Cidade Universitária, São Paulo, CEP: 05508-020 

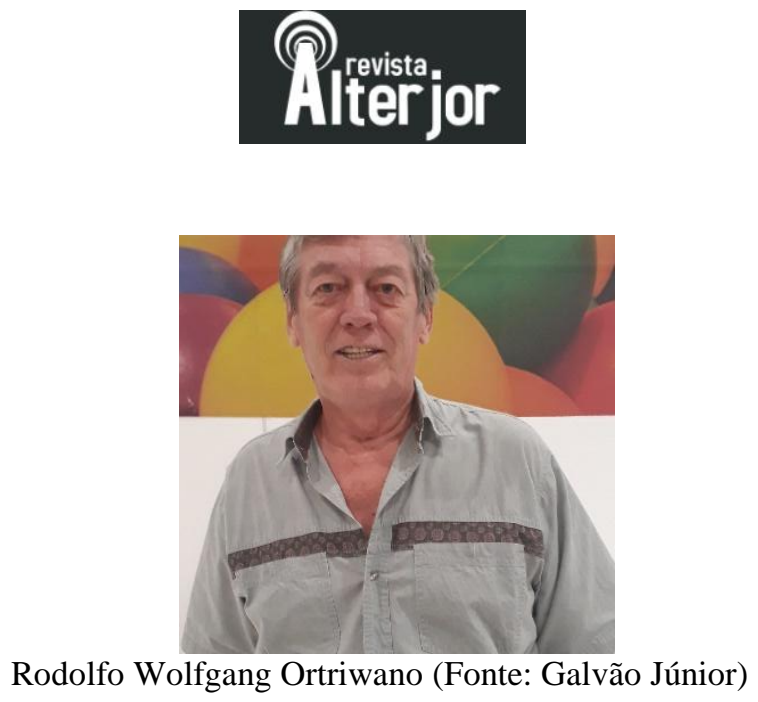

Filho caçula de Wassili Ortriwano e Barbara Domenica Maria Stampfel, casal europeu que aportou no Brasil depois da segunda guerra mundial, Rodolfo teve mais dois irmãos: Herbert, que faleceu em 2017, aos 62 anos; e Gisela, também falecida, mas em 2003, aos 55 anos. Graduado em Jornalismo pela Faculdade Cásper Líbero, Rodolfo atuou com destaque em emissoras de rádio por mais de 40 anos, com passagens pela Excelsior, Eldorado e Jovem Pan, onde editou o Jornal da Manhã até se aposentar, em 2007. Ex-professor e coordenador do curso de Jornalismo da Universidade Braz Cubas, em Mogi das Cruzes, São Paulo, Rodolfo - pai de André e Fernando - alegou ser, em entrevista ${ }^{2}$, um dos últimos remanescentes da família Ortriwano.

Irmã mais velha de Rodolfo, Gisela consolidou a carreira docente na ECA/USP, onde trabalhou entre 02 de março de 1974 até pouco antes de 19 de outubro de 2003, o dia de seu falecimento. Teve formação acadêmica também dedicada à Universidade de São Paulo, onde obteve a licenciatura e o bacharelado em Ciências Sociais pela Faculdade de Filosofia, Ciências e Letras, em 1971; e o bacharelado em Jornalismo pela Escola de Comunicações e Artes, em 1972. Professora Gisela Ortriwano tornou-se, em 1982, Mestre em Ciências da Comunicação ao defender a dissertação que gerou seu livro mais famoso, A informação no Rádio: os grupos de poder e a determinação dos conteúdos, editado pela Summus Editorial desde 1985. Outra conquista da docente foi a

\footnotetext{
2 Concedida em 13 de janeiro de 2020, em São Paulo, a entrevista é parte da pesquisa de pósdoutoramento "Modelo Giselista para o ensino da comunicação: a contribuição de Gisela Swetlana Ortriwano ao Jornalismo", de autoria deste autor, com início em abril de 2019 e encerramento em abril de 2021. Disponível em: <http://www3.eca.usp.br/sites/default/files/webform/projetos/posdoc/projeto_pos_doc_lourival_da_cruz_galvao_junior.pdf?keepThis=true $\&$ TB_iframe=true $\&$ height $=500$ \&width=800>. Acesso em: 05 jun. 2020.
} 


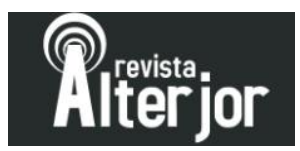

obtenção do título de Doutora em Ciências da Comunicação, em 06 de junho de 1990, com a defesa da tese Os (des)caminhos do radiojornalismo (ORTRIWANO, 1988). A pesquisa doutoral é a primeira feita no Brasil que trata, especificamente, de Radiojornalismo. A obra "é considerada hoje um estudo seminal, de uma pesquisadora nacionalmente reconhecida. Entretanto, a tese nunca foi publicada como livro, ainda que seja constantemente citada como pesquisa acadêmica" (LOPEZ, MUSTAFÁ, 2012).

Para conhecimento deste percurso com vistas à preservação desta memória e obra observou-se, como oportuno, ouvir pessoas que conviveram com a docente nos âmbitos acadêmico, pessoal e profissional. Dentre estes destaca-se Rodolfo Ortriwano, não apenas pelo fato de ser irmão, mas também jornalista e professor que acompanhou a trajetória de Gisela em todos os contextos citados. Para tal fim, a entrevista adotou os fundamentos da História Oral, que dispõem de um conjunto de procedimentos envolvendo a elaboração de um projeto que definirá determinados indivíduos a serem entrevistados para um devido fim documental (BOM MEIHY, 1996).

As declarações de Rodolfo Ortriwano revelaram um rico itinerário biográfico que teve origem no pós-guerra em Füssen, Alemanha, pequena cidade bávara aos pés dos Alpes, ao norte da fronteira com a Áustria. Naquela localidade Gisela nasceu, no dia 07 de junho de 1948. Segundo o entrevistado, o pai era apátrida, ou seja, não possuía nacionalidade regulamentada, apesar de ter lutado pela Rússia durante a invasão alemã à Leningrado, atual São Petersburgo. Rodolfo conta ainda que Wassili foi feito prisioneiro e noutra situação, levado à Alemanha ferido, conheceu Maria, que era enfermeira. Aquele encontro terminou, após a guerra, em um matrimônio que ultrapassou Oceano Atlântico e desembarcou no Brasil. Aqui, Wassili e Maria criaram Gisela e os irmãos Herbert e Rodolfo, ambos nascidos em São Paulo, respectivamente, nos anos de 1953 e 1955. É deste ponto que são destacados os principais trechos da entrevista com Rodolfo Ortriwano, apresentados a seguir ${ }^{3}$.

\footnotetext{
3 A transcrição ipsis litteris da entrevista gravada em áudio adota sinais estabelecidos pelo NURC/SP (Projeto de Estudo da Norma Linguística Urbana Culta de São Paulo - Núcleo USP), conforme Preti (1999), visando o estabelecimento da coesão e coerência textual. Para esclarecimento, os sinais adotados apresentam os seguintes significados: parênteses ( ） abrigam hipóteses do que se ouviu; reticências [....] são qualquer pausa; e aspas [“" "] são indicação de citações literais.
} 


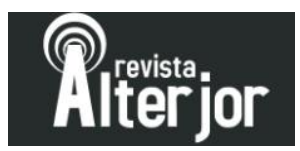

Galvão Júnior: Como foram os últimos dias da família Ortriwano na Alemanha?

Rodolfo Ortriwano: (Quando meus pais se) casaram, em 1947, a Alemanha estava destruída e (os americanos) prometeram para eles que quem quisesse ir para a América eles iriam mandar. Eles tiveram uma promessa dos americanos: "vocês querem ir para a América? Nós vamos mandar!". Estava tudo destruído; a Alemanha passando fome. Ofereceram essa viagem, mas só falaram América. Daí (meus pais) pegaram o navio, que passou em Casablanca, (no Marrocos). Minha mãe falava muito de Casabranca... Atravessar o oceano, naquele tempo, eram meses. Só que a América que eles prometeram era a América do Sul. Era o Brasil! Eles todos pensando que era os Estados Unidos, a América. Não! Era a América do Sul. Vieram para cá, desceram no Rio de Janeiro, desembarcaram. Tenho até esse documento do desembarque deles no Rio de Janeiro e, de lá, (os imigrantes) foram espalhados. Veio uma parte para São Paulo. Trabalharam muito duro. Ortriwano é um nome assim, que eu falo: eu não sei se é verdade, porque quando vejo algum documento do meu pai, está "local de nascimento: Albania”. Não (tem um documento que) fala de São Petersburgo, Leningrado. Meu pai nunca falou ou quis falar dessas coisas. Até hoje eu não sei se me chamo Ortriwano. Não sei se ele inventou esse nome para ficar na Alemanha. Eu realmente não sei, não sei. Eu não posso dizer. Então se você pegar o Google, entrar, no mundo inteiro não existe Ortriwano, fora meus dois filhos e eu. A minha família Ortriwano morreu inteira. Ficaram meus dois filhos. Então ascendentes acabaram e são dois descendentes Ortriwano. Meu pai dizia que eram 19 irmãos lá, em São Petersburgo, lá em Leningrado. Só que (ele) nunca mais viu ninguém. Então ele não sabe o que aconteceu. Eu não tenho nenhum contato com o lado paterno. Nada! Nem da Rússia, nem de lugar nenhum. Então realmente eu não sei. Agora, minha mãe, sim. Ela tinha um irmão que morreu na guerra e, a irmã, essa fui visitar em 2012. Essa irmã tem sete filhos, que são meus sete primos legítimos. Então é assim. A história é bastante complicada. Vitoria era minha avó (materna). Fui na Alemanha, peguei o certificado de nascimento de minha mãe no cartório de lá... tudo certinho. Tentei um passaporte alemão que eu achava direito meu: sou filho legítimo de alemão, mas o consulado me negou, dizendo que pela 


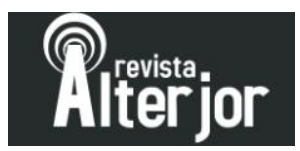

lei de 1953 o alemão que se casasse com estrangeiro perdia a nacionalidade. Então entrei com recurso dizendo que meu pai não tem nacionalidade - está escrito aqui apátrida. Se uma pessoa é apátrida ela não tem nacionalidade. Mas não adiantou. Perdi o recurso, gastei uma grana e me negaram o passaporte. Tinha muito mais interesse de ter um passaporte europeu por causa dos filhos.

Galvão Júnior: Como foi a vinda dos Ortriwano para o Brasil?

Rodolfo Ortriwano: Eles (os pais) foram espalhados pelo próprio governo brasileiro. Eles vieram parar aqui em Campo Limpo (bairro da zona sul de São Paulo), se não me engano. (Foi o) primeiro lugar que eles vieram parar. Depois meu pai dizia que ele estudava veterinária, mas que na guerra ele aprendeu um pouco de mecânica. E com o tempo ele arrumou um emprego de mecânico, de auxiliar, de alguma coisa, aqui na antiga Vigor (cooperativa) de leite, aqui no Pari. Daí eles mudaram para a Vila Maria (bairro da zona norte). E lá eles só tinham a Gisela, pequena. Eu sou registrado na Vila Maria, nasci em São Miguel (Paulista), mas meu pai só conhecia lá. Então me registrou lá. Mas, assim: eu e meu irmão nascemos em São Miguel, no parque Cruzeiro do Sul. Lá, com o emprego dele, (meu pai) comprou uma casinha no parque Cruzeiro. Ele veio morar, vinha trabalhar de ônibus e tudo mais. Era mecânico de caminhão. Aí ele resolveu fazer uma oficina. Em (19)64 ele abriu a oficina. Em 63 ele trabalhava e iria fazer dez anos de Vigor; na época não tinha fundo de garantia, mas tinha estabilidade de emprego. Então quando chegava a dez anos ninguém mais podia mandar você embora. Por isso foi criado o Fundo de Garantia, porque (quando) chegava em nove (anos) você era demitido. Nenhuma empresa queria ficar com o cara para o resto da vida. Ele sabia que iria ser demitido. Depois do governo militar é que veio o Fundo de Garantia para evitar esse problema. Aí ele foi demitido mesmo e, enquanto isso, ele ficou fazendo (a instalação da) oficina. Andava a pé sete quilômetros, sábado e domingo. Ia e voltava para fazer aquela oficina. Aí ele conseguiu. Ficou com aquela oficina até morrer. Morreu embaixo de um carro, de ataque do coração, consertando um carro. O 


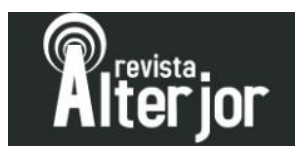

falecimento dele foi em 86. Ele era mais funileiro. Daí ele contratou mecânico e pintor. Com o tempo foi ficando ele só na funilaria.

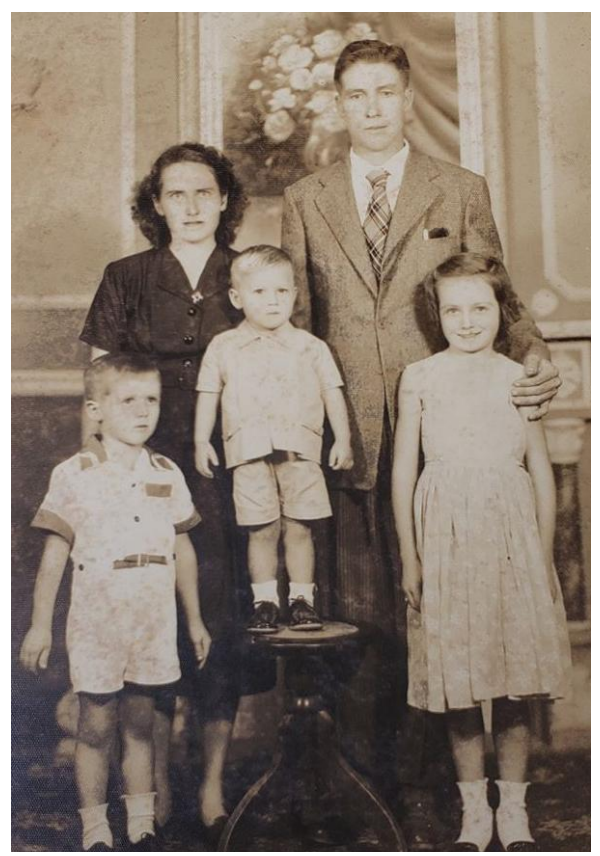

Família Ortriwano (Fonte: Arquivo pessoal / Rodolfo Ortriwano)

Galvão Júnior: Vocês falavam alemão em casa?

Rodolfo Ortriwano: A minha mãe e meu pai só falavam alemão. Eu tenho um padrinho, que já faleceu também, chamado Wladimir Ostapenko. Este sim era Ucraniano! O Ostapenko ia lá em casa e eles falavam russo; eles dois, meu pai e meu padrinho. Eu não entendia nada. Agora, em casa, com minha mãe, era só alemão. Minha mãe falava só em alemão com a gente e hoje eu não falo uma palavra em alemão. Deu um breque, zerou minha cabeça, não mais consigo falar. Fui na Alemanha e não consegui (falar). Minha tia falava, eu entendia tudo o que ela falava e (eu) não conseguia responder um “a”. Incrível isso. É loucura. Deu um bloqueio. Eu falava em inglês, um pouco, e daí a neta dela falava, explicava... coisa maluca, né. Mas era alemão (que se falava em casa), direto. 


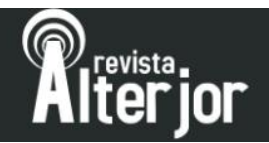

Galvão Júnior: O fato de falar alemão e português (em casa) foi um diferencial? Creio que havia uma preocupação da Maria e do Wassili com a educação de vocês...

Rodolfo Ortriwano: Sempre, sempre teve. Isso aí era uma das coisas que meu pai e minha mãe (priorizavam). A gente tinha que ir trabalhar para comprar o lápis, tudo, mas não podia faltar na escola. Antes da oficina, enquanto (meu pai) montava a oficina, eu vendia sorvete, puxava uns carrinhos na feira. As mulheres iam fazer compras, enchiam os carrinhos... eu levava os carrinhos; era normal. Engraxava uns sapatos de sábado num barzinho lá em frente. Era moleque e tinha que ter uma graninha.

\section{Galvão Júnior: E a Gisela?}

Rodolfo Ortriwano: A Gisela sempre foi protegida do meu pai. A Gisela nunca precisou (de) nada. Eu e meu irmão tínhamos que trabalhar até para comprar os livros. Mas ele não deixava faltar (nada para todos). Meu pai foi na minha formatura de ginásio, na minha formatura de colégio e na minha formatura de faculdade. Para mim era importantíssimo isso. Mas eles influenciaram demais, sabe, realmente. Tinha que estudar. Pode ser pobre, mas tem que estudar. Até os meus filhos... minha mãe começava a conversar com eles, falava um pouco em português e depois acabava falando em alemão. E eles acabavam entendo. Iam pelo gesto, assim. Ela costurava um pouco, tinha poucos amigos; uma vida isolada. Meu pai não. Ele trabalhava fora, né. Ele tinha facilidade de falar português. Minha mãe, não. Era muito mais difícil. (Ela ficava) só lá dentro de casa. (Era) aquela senhora antiga: lava louça, lava roupa, faz comida. Nós tínhamos café da manhã, almoço, café da tarde e janta. Todo dia o horário certo, todo mundo sentava junto, a família. Coisa incrível. Hoje não existe mais.

Galvão Júnior: Esse pragmatismo influenciou no cuidado com a educação?

Rodolfo Ortriwano: Minha irmã teve um privilégio muito grande. Primeiro porque ela era mais inteligente do que eu, com certeza. Primeiro porque ela foi fazer USP e eu fiz 


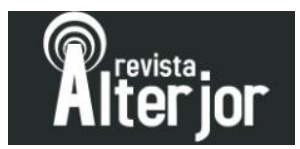

Cásper Líbero. Ela fez Ciência Sociais, entrou na USP; fez Comunicação, entrou na USP. Eu tenho umas amigas do Dom Pedro (escola onde Gisela e Rodolfo estudaram), dessa turma. Ela era um pouco mais velha do que eu. Ela terminou o colégio, no mesmo colégio nós estudamos. Ela (a Gisela) era da turma do Antonio Marcos. Lembra daquele cantor? Era da mesma turma. Ele tinha o conjunto chamado "Os Intocáveis" naquela época. E ele foi expulso do colégio por causa do cabelo. Dona Daisy era diretora: "ou você corta o cabelo ou não entra na escola". Meu pai dava tudo para ela. Fazia tudo, tudo, tudo para ela. Ela era a mais inteligente da turma. Era também a mais bonita. Era a rainha do colégio. Era muito bonita, magrinha, mas era muito fechada. Pouquíssimos amigos. Eu conheci dois, três, quatro amigos. (Gisela) estudava muito. Depois foi morar na Crusp (conjunto residencial da USP). Tinha uma vida assim, dedicada total(mente aos estudos).

Galvão Júnior: A vida de vocês sempre foi em São Miguel? Estudaram no bairro?

Rodolfo Ortriwano: Antigamente era primário, ginásio e colégio dividido em opções: ou você fazia o normal para ser professor, ou fazia o clássico, ou fazia o científico. Era dividido. Depois cada um ia para sua turminha. Então ela fez o Dom Pedro, que era o Francisco Roswell Freire ${ }^{4}$. Eu também comecei no Francisco Roswell Freire. Naquele tempo a gente tinha latim, era aula obrigatória; francês, era aula obrigatória. Mas, nos grupos anteriores... eu lembro que estudei no grupo do Parque Cruzeiro (do Sul), que era de madeira. E só tinha até o terceiro ano. Tinha que se virar e fazer o quarto. E para você sair do quarto ano primário e ir para o ginásio tinha que fazer a admissão: chamava-se admissão ao ginásio. Tinha que fazer um exame. Não entrava direto assim. Era terrível. O pessoal pagava cursinho naquela época só para fazer a admissão. E ela (Gisela) entrou direto. Eu também entrei direto. Mas o Dom Pedro era o melhor

\footnotetext{
${ }^{4}$ Nome dado posteriormente ao ginásio estadual de São Miguel Paulista, criado em 1952, que ocupava o espaço do grupo escolar Carlos Comes. Devido ao aumento no número de alunos, o edifício não atendia mais às exigências necessárias para manter-se como entidade educacional. Por fim, o grupo escolar foi desativado para ser transferido para um novo prédio a ser construído, a escola Dom Pedro I, localizada na rua Américo Gomes da Costa, entre a avenida nordestina, antiga estrada do lajeado - que levava a Santos, e a avenida Marechal Tito, antiga estrada São Paulo - Rio de janeiro. Disponível em:<http://www.fau.usp.br/disciplinas/tfg/tfg_online/tr/072/a048.html>. Acesso em: 10 jun. 2020
} 


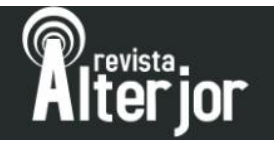

colégio... é considerado um dos melhores em São Paulo. Era uma coisa muito séria mesmo, muito séria.

Galvão Júnior: E os jornais Pirilampo e Coruja?

Rodolfo Ortriwano: Uma das coisas que o colégio exigia da gente (era) essa criação. Era uma criação. A gente fazia um jornal! E o Pirilampo, por exemplo, eu escrevia tudo a mão. Era uma edição única. A gente colocava edição única. Punha os nomes dos redatores. Esse Pirilampo, a matéria de página, era a viagem dela (Gisela) pelo projeto Rondon para o Macapá. Era, Nossa Senhora, meu Deus do Céu! Era mil novecentos e sessenta e tanto... onde é Macapá, meu amigo? Fizemos uma entrevista com ela. Eu e os colegas fizemos as perguntas e eu a entrevistei em casa. E era (chamada) para a página principal. Mas era assim. O colégio obrigava. Toda classe masculina tinha uma horta. Tinha que cuidar de uma horta. E as classes femininas aprendiam corte e costura. É uma coisa hoje impensável! Era uma educação bem completa. Tinha educação física obrigatória, um anfiteatro maravilhoso (onde) que tinha que fazer peça de teatro; tinha que encenar peças. Era diferente. Hoje você fala do colégio, o aluno batendo no professor. Havia um respeito muito grande.

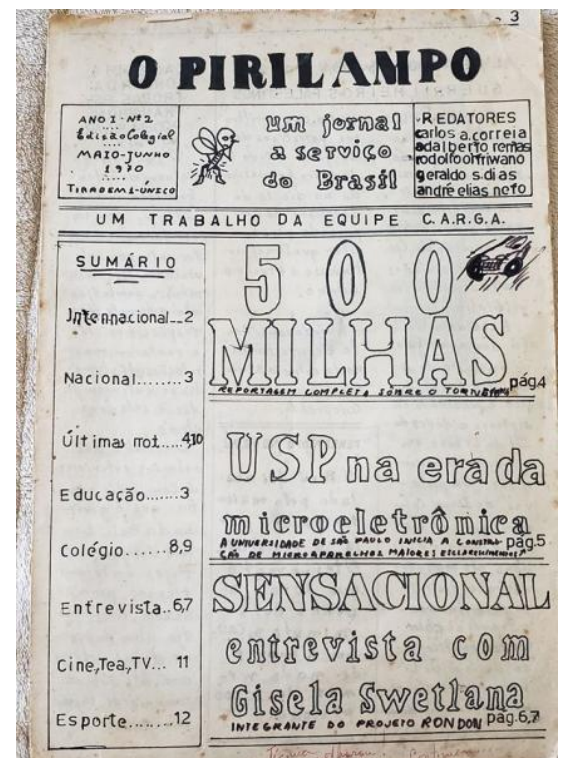

Jornal Pirilampo com chamada para a entrevista com Gisela

(Fonte: Arquivo Pessoal - Rodolfo Ortriwano)

Revista ALTERJOR

Grupo de Estudos Alterjor:Jornalismo Popular e Alternativo (ECA-USP)

Ano 10 Volume 02 Edição $22 \quad$ Juho- Dezembro de 2020

Avenida Professor Lúcio Martins Rodrig̉ues, 443, Cidade Universitária, São Paulo, CEP: 05508-020 


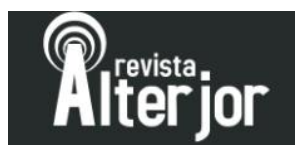

Galvão Júnior: O contato de Gisela com o jornalismo teria nascido aí?

Rodolfo Ortriwano: Para mim, sim. Eu não sei ela (Gisela). Ela fez Ciências Sociais (na USP). De lá ela fez Comunicação Social. (O jornal Coruja) deve ter influenciado sim$^{5}$.

Galvão Júnior: ela não conversava sobre este tipo de assunto?

Rodolfo Ortriwano: Não. Era muito raro. Quando ela foi escrever o livro (A Informação no Rádio) ela falou muito comigo. Eu fazia o Jornal Ouça da (Rádio) Excelsior e eu tinha o dia a dia ali. Ela não tinha o dia a dia do jornalismo, do estúdio. Eu estava ali com Heródoto Barbero; era fácil para mim. Daí conversamos bastante profissionalmente.

Galvão Júnior: Nesse período ela nunca falou sobre o desejo de fazer jornalismo?

Rodolfo Ortriwano: (Ela) nunca falou o que iria fazer. Eu lembro, assim, que ela morava no Crusp (Conjunto residencial da USP) e eu fui lá, na época, 1968... época brava, de bomba, tinha carro queimado. Eu não entendia. Era cinco anos mais novo. Era tudo diferente. A minha visão do golpe... eu tinha 11 anos; ela já estava no colégio. Eu tinha uma visão diferente. Daí eu vi. Mas ela nunca foi de abrir. Nunca, nunca. Eu não sabia. Depois, sim. Depois ela falou: "vou para a TV Globo". (Ela) foi para a tevê e eu, fazendo aquele jornal (escolar) Pirilampo. O pessoal achava que eu tinha um dom, não sei o quê, e eu falei: “então é por aí que eu vou”. Mas eu fiz o científico, para garantir!

Galvão Júnior: Então na época em que o senhor foi para a Globo ela já estava envolvida com jornalismo...

Rodolfo Ortriwano: Não. Nessa época eu trabalhava num banco. Nessa época, em 1972, eu trabalhava na Mepasa - Mercantil Participações, que era o Banco Mercantil de São

\footnotetext{
${ }^{5}$ O Jornal Coruja, de acordo com Rodolfo Ortriwano, seguia metodologia similar ao Pirilampo e foi citado por ele antes da entrevista. Não foram encontrados exemplares desta publicação.
} 
Paulo. Ela saiu da Globo e foi para a Cultura. Ela estava na (TV) Globo. Ela falou assim: "você não quer ir trabalhar comigo na Globo?" Aí falei: "Nossa Senhora, acho que agora vai casar o negócio”. (Mas) estou no banco. Daí sai do banco e fui para a Globo; agosto de 72. Ela que me levou: agosto de 1972. Aí (a emissora) não registrava, não registrava... daí veio um documento da Globo do Rio (de Janeiro) dizendo que a Globo não admite parentes. Caramba! Era Paulo Mario Mansur o diretor e acabou resolvendo. Eu fui registrado em $1^{\circ}$ de janeiro de 1973. Aí nossa vida foi (seguindo) por mais uns anos, até 1975 juntos. Daí a gente tinha mais contato (com) as ideias dela. Ela montou na Globo uma coisa que a base de tudo até hoje. Esses DEDOC (Departamento de Documentação) que existem, esses sistemas de coisas. (O da Globo) foi montado na raça, cortando jornal.

Galvão Júnior: Havia mais alguém que trabalhou com vocês no Departamento de Pesquisa de Telejornais da TV Globo?

Rodolfo Ortriwano: Tem uma jornalista que trabalha até hoje na Globo: chama-se Assimina Vlahou; era uma grega. Ela está na Globo do Rio; acho que ela faz Globo Repórter. Até hoje está lá. A gente ainda conversa até hoje. Essa ainda continua. Outros amigos: o João Carlos Labruna trabalhou com a gente; era jornalista, mas foi parar em assessoria. Outros amigos: um virou advogado, é o José Wellington Porto - esse cara pode falar muito dela também.

Galvão Júnior: Como foi trabalhar lá no centro de documentação?

Rodolfo Ortriwano: Ela (Gisela) tinha as ideias e a gente punha em prática, na verdade. A gente era mão de obra. "Caiu um avião em tal lugar: Pesquisa! (Há) quantos aviões desse modelo caíram neste ano?". Não tinha (essa informação). (Eu) pegava um taxi, ia lá no arquivo do Estadão (Jornal O estado de São Paulo), ali no centro ainda, e lá no arquivo (anotava) as informações e trazia. Era um departamento que foi, assim, inovador em toda a comunicação. 
Galvão Júnior: Lembra como foi o convite para Gisela entrar na TV Globo?

Rodolfo Ortriwano: (Gisela) tinha terminado a faculdade. Acho que foi um dos projetos que ela apresentou. Se não me engano ela apresentou esse projeto para esse diretor (da TV Globo, que) chama Paulo Mário Carneiro da Cunha Mansur. Eu lembro bem porque o nome era cumprido; ele era de Santos. Ela foi chamada lá como experiência dessa criação. Ele viu um potencial muito grande (no projeto), porque um redator não tem (essa informação), não tem internet. Como achar uma informação dessa? Como se fazia isso? Nós recebíamos todos os jornais, todo dia. Lia o jornal todinho: "nossa, isso aqui pode interessar um dia": gilete, cola (a nota) num papel, (arquiva na) pasta "acidente". Era uma coisa de louco: papel, papel, papel. Isso ela levou para a casa. Passou a guardar papel em casa também. Então era muito difícil. Quem estava lá (e a) redação chamava: "tal coisa (aconteceu)... (resposta): está aqui (a informação)". Isso abriu minha vida também, para o jornalismo e para o conhecimento. Passei a conhecer tudo. Se você tinha um interesse " $x$ " você tinha que ler tudo. Isso me enriqueceu demais (e) foi nessa experiência com a Gisela. Foi essa ideia que ela tinha que foi comprada por todos. "Poxa vida, interessante demais". Mas eu era moleque... novo ainda. Daí eu fui para a Cásper Líbero. Daí eu aproveitei e, em 1973, fiz a Casper Líbero, que era difícil na época. Eu fiz Cásper Libero com Osmar de Oliveira, com o médico Carlos Gomes que já faleceu; com Ronaldo Esper que está aí até hoje. Eram amigos de turma. Na minha classe tinha um cidadão chamado Edson Arantes do Nascimento. Ele estava matriculado, mas nunca foi! O Carlos Nascimento era da minha turma. A Cásper Líbero era muito séria.

Galvão Júnior: Então Jornal Pirilampo levou o senhor a pensar em jornalismo e foi Gisela que lhe deu a primeira oportunidade...

Rodolfo Ortriwano: Aquele Pirilampo é de 1970; aquela edição que eu tenho. A gente tinha que todo mês fazer um. Aquele que ficou comigo é de 1970. Ele falava da Copa de 


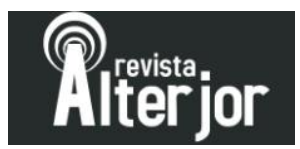

70; a gente dava resultado do jogo. Mas tinha a ideia de jornal. Tinha o comentário da professora: melhorou ou piorou. Era mensal essa edição. O primeiro ficou comigo. O pessoal jogava fora. Eu não! Guardava comigo. Era uma coisa importante.

Galvão Júnior: como era trabalhar com Gisela? Era metódica, exigente?

Rodolfo Ortriwano: Sempre metódica, sempre exigente e sempre distante. Mesmo sendo irmão não havia nenhuma facilitação e nem uma conversa a mais. Ela comprou esse carro (Volkswagen TL); foi da Maria de Lourdes Ferreira Martins, que era mulher do (locutor) Ferreira Martins. Só que ela (Gisela) não dirigia. Então quem ficou com o carro foi eu: saia de casa, a levava. Depois eu comprei um corcelzinho (Ford Corcel e) ela ficou com o TL e começou a dirigir. Ela era tão apegada às coisas que nunca vendeu (o TL). Comprou o (Volkswagen) Passat e nunca vendeu. Comprou tudo zero. Esse TL tinha mil quilômetros.

Galvão Júnior: O TL era de um único dono...

Rodolfo Ortriwano: Único dono. Passei para meu nome assim que (saiu) o inventário, para não ter problema; mas o dono era só ela. Como não tinha mais como cuidar e o meu cunhado cuida muito (de carros), então passei para ele, que tem autoescola. Não sei se esse TL está na autoescola. Ele ia colocar lá de destaque. A Gisela, no serviço, cobrava muito: horário, fazer as coisas. Mas não havia assim um relacionamento, por ser irmão, diferenciado, não.

Galvão Júnior: Ela trabalhou também na produção de programas jornalísticos e destaca um documentário, Globo Shell Especial, sobre o primeiro título de Fórmula 1 do Brasil.

Rodolfo Ortriwano: Isso. Na Fórmula 1, ela fez um trabalho muito grande com Emerson Fittipaldi, em 1972, se não me falha a memória. Ela fez depois um negócio que era uma 


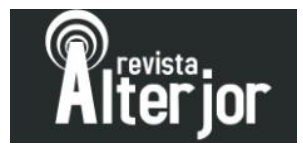

moda, uma corrida de cavalo... aquela com uma carrocinha que vinha atrás, na Vila Guilherme $^{6}$. Tipo uma biga. Ela mesmo chegou a correr para sentir e fazer uma matéria dessas. Ela produzia sim, produzia matérias. E uma das coisas que a gente participou muito foi do Jornal Hoje (da TV Globo). Em (19)73 começou. Porque ali, quem foi apresentar, quem que era? Era uma mocinha, novinha e bonitinha chamada Marília Gabriela. Aparecia nosso nome como produtores do Jornal Hoje, com música de Peter Paul Berrie (ao fundo da subida dos caracteres). Foi uma coisa bacana. Nessa época também começou o Fantástico e (também) aparecia o nome da gente, sempre diferenciado. O meu era Rodolfo Ortriwano e o dela Gisela Swetlana; para não aparecer os dois Ortriwano. E domingo tinha Silvio Santos, que comprava o domingo inteiro da Globo. Como foi criado o Fantástico aí começou o plantão de domingo. Ai meu Deus do céu! A gente não trabalhava domingo, né... e daí tinha que ir domingo. Daí subia um pouquinho, tomava alguma coisa e voltava lá para o teatro que ficava na Marechal Teodoro para assistir o Silvio Santos. Tempo bom, viu!

Galvão Júnior: Na TV Cultura Gisela atuou em um departamento semelhante ao que havia sido criado na Globo. Lá ela ajudou a produzir um documentário sobre João Paulo II, em 1980. Conhece essa trajetória?

Rodolfo Ortriwano: Lembro que ela fez essa produção. Nessa época eu estava no sistema Globo de Rádio e estava fazendo o Jornal Ouça, da Rádio Excelsior.

Galvão Júnior: Ela teve outras experiências profissionais?

Rodolfo Ortriwano: Ela dava muito curso: Barcelona, na Espanha; Brasil inteiro (até) Belém do Pará. Dava muito curso. Viajava muito mesmo. Mas nenhum outro, assim, que eu possa falar: este foi um emprego. A experiência dela foi didática: professora da USP, professora da Metodista de São Bernardo (do Campo), professora em Itapetininga, professora na UNAERP de Ribeirão Preto. E quando ela não podia dar aula eu ia dar

\footnotetext{
${ }^{6}$ Ações promovidas pela Sociedade Paulista de Trote.

Revista AL TERJOR

Grupo de Estudos Alterjor:Jornalismo Popular e Alternativo (ECA-USP)

Ano 10 Volume 02 Edição $22 \quad$ Juho- Dezembro de 2020

Avenida Professor Lúcio Martins Rodriģues, 443, Cidade Universitária, São Paulo, CEP: 05508-020
} 


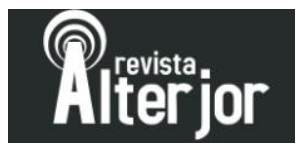

aula lá em Ribeirão Preto. Ela não podia em um sábado, eu ia. Era assim. Ela tinha confiança em meu potencial. Ela deu aula nas Braz Cubas também!

Galvão Júnior: $O$ senhor trabalhou em grandes emissoras de rádio, como Eldorado, Jovem Pan, Sistema Globo de Rádio. Qual foi sua influência na carreira acadêmica da professora Gisela?

Rodolfo Ortriwano: Toda a experiência (profissional) dela foi de tevê. Eu não sei onde ou qual foi o fio da meada para ela ter ido para o rádio. Eu nunca soube o porquê. Ela (tinha) o trabalho acadêmico dela dentro da USP. Ela fazia os estudos de rádio e televisão, mas muito mais de televisão, lá na USP também. Mas eu achava, sim, que ela se dedicou mais ao rádio porque era um veículo que ela gostava mais; alguma coisa desse tipo. Aí ela começou a falar mais comigo. Eu era do rádio e, aí sim: nós conversamos muito tempo mesmo. (Na época da dissertação) ela fazia (os textos), mandava para mim... aí eu fazia uma anotação ou outra, mandava de volta. Ela começou a falar comigo de rádio. "Estou aqui". Era editor do jornal da manhã. "Se eu puder ajudar falo com Heródoto (Barbeiro), com o Celso Freitas, com o Miguel de Oliveira, com o Luiz Carlos Marquesi”...

Galvão Júnior: $O$ que levou o senhor ao rádio, já que começou com Gisela na televisão? Ela também contribuiu?

Rodolfo Ortriwano: Quando eu fui para o rádio, o Hélio Jacinto que me chamou e (ele) era amigo da Gisela. Ele era diretor do Sistema Globo de Rádio - Jornalismo. Ele conversou com ela: "estou precisando de alguém". E ela falou: "fala com o meu irmão. Ele gosta de rádio". Eu gostava de rádio. Daí ele me chamou e eu fui fazer (rádio). (Pensava): eu faço texto de tevê, mas no rádio deve ser a mesma coisa. A diferença é que eu não tenho imagem. Então eu vou criar um texto com imagens. Só isso. E era uma coisa que eu fazia fácil. Faço até hoje. Minhas crônicas são um texto com imagens. A pessoa lê e ela fala: "eu estou vivendo isso". É você criar uma imagem. Porque a 


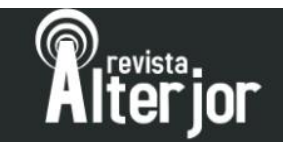

televisão facilita muito o seu texto. O rádio, antigamente, tinha os apresentadores fantasmas; ninguém sabia quem era. Só sabia da voz. Era um mistério. O rádio era um mistério. Depois o pessoal (do rádio) passou para a televisão e passou a ser conhecido. Quem era Luiz Lopes Correia $^{7}$ ? Eu saia com ele à noite. Era muito gente boa. O pessoal era diferente; era um jornalismo diferente. A gente saia da Excelsior, terminava o Jornal Ouça às sete horas, na hora da Voz do Brasil, saia e ia na padaria tomar uma cerveja. Mas ia discutir o jornal, entendeu? "Pô, que m... você fez. Pô, aquele texto está errado!". Era incrível. Havia uma ligação muito forte da gente com a informação e com a responsabilidade.

Galvão Júnior: A Gisela tinha contato com esses profissionais?

Rodolfo Ortriwano: Tinha sim. (E também com) o Milton Parron, que é meu amigo também. Se você conversar com Parron ele vai ter boas lembranças da Gisela. Tinha o Maurício Calil, que morreu agora faz pouco tempo... era da Rádio USP. Mas ela só queria a USP mesmo. O negócio dela era a USP e só.

Galvão Júnior: Como o senhor acompanhou a trajetória dela na USP?

Rodolfo Ortriwano: Eu era o irmãozinho mais novo e ela falava comigo: "vamos lá [na USP]". E eu ia acompanhando. Em [19]68 eu tinha 15 anos. (Era) bem menor o meu conhecimento. Ela tinha 20 (anos). Mas era muito rápida essa mudança. Até hoje é muito rápido. Eu acompanhava muito no começo: "vou fazer isso, vou fazer aquilo". Mas depois ela não falava mais dos planos, dos projetos. Eu fui até um certo período. Acompanhei bastante, no tempo do TL. Depois a gente foi distanciando.

\footnotetext{
7 Atuou em emissoras de rádio e televisão. Ficou conhecido por trabalhar no extinto telejornal "Aqui Agora", do SBT, onde lia as manchetes na abertura do programa e respondia pela narração das matérias internacionais do telejornal. Faleceu em 1999.
}

Revista ALTERJOR

Grupo de Estudos Alterjor: Jornalismo Popular e Alternativo (ECA-USP)

Ano 10 Volume 02 Edição $22 \quad$ Juho- Dezembro de 2020

Avenida Professor Lúcio Martins Rodrig̉ues, 443, Cidade Universitária, São Paulo, CEP: 05508-020 


\section{Pliterior}

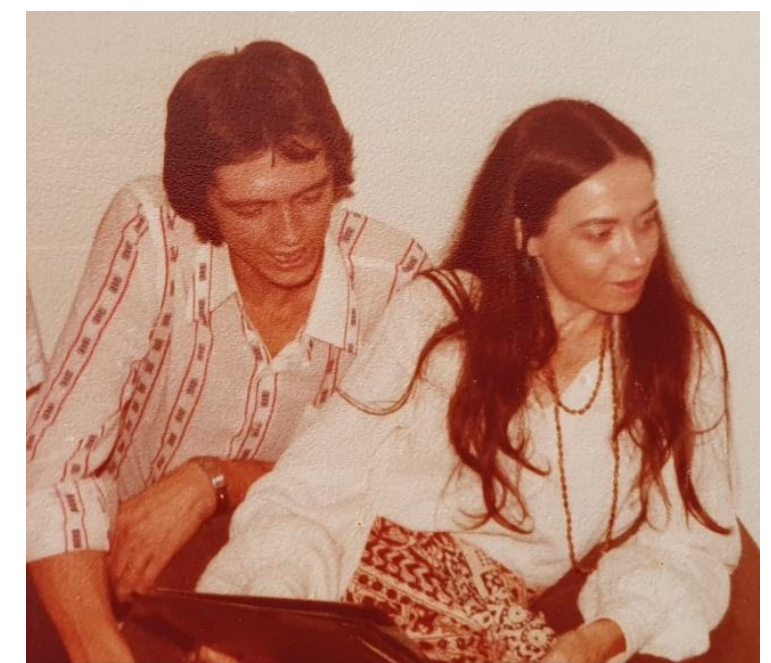

Rodolfo e Gisela - Década de 1970 (Fonte: Arquivo Pessoal / Rodolfo Ortriwano)

Galvão Júnior: Qual o legado que Gisela deixou para o jornalismo e para o rádio?

Rodolfo Ortriwano: Gisela era tão contemporânea... apesar do tempo, nós estamos há 17 anos da morte dela e o livro (A Informação no Rádio) já foi escrito há 35 anos e é base até hoje. Ela era visionária. Ela tinha uma linguagem fácil, simples e ela entendeu como era o radiojornalismo. Ela falou dos grupos de pressão sobre o rádio e falou de coisas que não se discute. A verdade é essa. Se omite muito (sobre) o rádio. Eu lembro muito bem. Até na Jovem Pan, onde fiquei muitos anos, diziam: "teve um assalto no banco X.... não, não fala o nome do banco, não!”. Sabe essa censura econômica... A Gisela tinha toda essa visão. O legado dela é uma obra que não termina; é uma obra que não acabou. Está sempre ali. Você pode acrescentar, mas você não a altera, não muda a estrutura. É aquilo. 


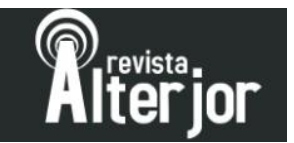

\section{Referências}

BRAGA, Milton; DELIJAIKOV, Alexandre; MAYUMI, Lia. Convênio Escolar: análise e intervenção. Faculdade de Arquitetura e Urbanismo da Universidade de São Paulo (FAU/USP), 2007. Disponível em:

<http://www.fau.usp.br/disciplinas/tfg/tfg_online/tr/072/a048.html>. Acesso em: 10 jun. 2020

BOM MEIHY, José Carlos Sebe. Manual de história oral. São Paulo: Edições Loyola, 1996. $78 \mathrm{p}$.

BRAIT, Beth. O processo interacional. In: PRETI, Dino (org.). Análise de Textos Orais. 4. ed., São Paulo: Humanitas, 1999, p. 189 - 214, Projetos Paralelos - Nurc/SP.

GALVÃO JÚNIOR, Lourival da Cruz. Modelo Giselista para o ensino da comunicação: a contribuição de Gisela Swetlana Ortriwano ao Jornalismo. Projeto apresentado ao Programa de Pós-Graduação da ECA/USP como requisito para desenvolvimento de pesquisa em Pós-doutorado. Disponível em: <http://www3.eca.usp.br/sites/default/files/webform/projetos/posdoc/projeto_pos_doc_lourival_da_cruz_galvao_junior.pdf?keepThis=true\&TB_iframe= true\&height $=500 \&$ width $=800>$. Acesso em: 05 jun. 2020.

LOPEZ, Débora Cristina; MUSTAFÁ, Izani. Pesquisa em rádio no Brasil: um mapeamento preliminar das teses doutorais sobre mídia sonora. In: Revista Matrizes, vol. 6, p. 189-205. São Paulo: EdUSP, 2012.

ORTRIWANO, Gisela S. Memorial. Requisito para ingresso à carreira docente junto às disciplinas Radiojornalismo e Telejornalismo. São Paulo: ECA/USP, 1988. 